\title{
Effects of Hardening Methods on Seedling Characters, Germination and Nodulation in Greengram (Vigna radiata L.)
}

\author{
Shivanisingh*, A.K. Chaurasia, Bineeta M. Bara and Vijay Dugeskar \\ Sam Higginbottom University of agriculture Technology and sciences, Allahabad (UP), India \\ *Corresponding author
}

\begin{tabular}{|c|c|}
\hline & A B S T R A C T \\
\hline Keywords & \multirow{8}{*}{$\begin{array}{l}\text { The experiment was conducted in Post Graduate Laboratory and Field Experimentation } \\
\text { Centre of Department of Genetics and Plant Breeding, Sam Higginbottom University of } \\
\text { Agriculture, Technology and sciences, Allahabad (U.P.), in order to standardize the } \\
\text { suitable hardening chemicals (organic or Inorganic) for Greengram seeds (var. Samrat). } \\
\text { Four different Organic and Inorganic Solutions viz., } \mathrm{T}_{0} \text {-Untreated (Control), } \mathrm{T}_{1} \text {-Hardened } \\
\text { with Distilled water, } \mathrm{T}_{2} \text {-Hardenedwith } \mathrm{KNO}_{3} 20 \%, \mathrm{~T}_{3}-\text { Hardenedwith } \mathrm{NaCl} 1 \% \text {, } \mathrm{T}_{4} \\
\text { Hardened with } \mathrm{CaCl}_{2} 1 \%, \mathrm{~T}_{5}-\text { Hardened with Tulsi leaf extract and } \mathrm{T}_{6}-\mathrm{Hardened} \text { with } \\
\text { Neem Leaf Extract } 5 \% \text { were taken and in their solutions seeds hydrated for } 12 \text { hours and } \\
\text { then dried for } 24 \text { hours in shade. It was found that among all the Hardening treatments } \\
\text { showed significance difference with the control while highest germination percentage, } \\
\text { seedling length and weight, vigour index, and nodulation were observed for seeds treated } \\
\text { with } \mathrm{KNO}_{3}(20 \% \text { Solution). This study also showed that Seed Hardening with neem leaves } \\
\text { extracts, Tulsi leaf extract, CaCl }{ }_{2} \text { and distilled water were found to increase the seedling } \\
\text { character, growth and yield. The study helps to improve the seedling character, growth and } \\
\text { nodulation with the help of seed Hardening treatments which are cost effective, economic, } \\
\text { non-toxic and from eco-friendly sources. }\end{array}$} \\
\hline & \\
\hline Methods, & \\
\hline $\begin{array}{l}\text { Treatments, } \\
\text { Germination, }\end{array}$ & \\
\hline $\begin{array}{l}\text { Seedling } \\
\text { Characters, Neem }\end{array}$ & \\
\hline Leaf Extract, $\mathrm{CaCl}_{2}$ & \\
\hline Artic & \\
\hline $\begin{array}{l}\text { Accepted: } \\
\text { 23 August } 2017 \\
\text { Available Online: } \\
\text { 10 September } 2017\end{array}$ & \\
\hline
\end{tabular}

\section{Introduction}

Pulses constitute an important ingredient in predominantly vegetarian diet and are important source of protein that nutritionally balances the protein requirement of vegetarian population. They supply minerals and vitamins and provide an abundance of food energy. Pulses provide a cheaper source of nutrients/ proteins as they generally contain nearly twice as much as protein as that of cereals and hence correctly called poor man's meat. Pulses are also important for sustainable agriculture enriching the soil through biological nitrogen fixation, fixes about 40-50 $\mathrm{kg}$ of N/ha (Hariprasanna and Bhatt 2002).
When nitrogen is supplied either through inorganic or organic source to the crop, the increase in chlorophyll occurs (Austin et al., 1973). Greengram is one of the important pulse crops in India. Greengram (Vigna radiata L.) $(2 \mathrm{n}=22)$ is a self-pollinated legume crop originated in South Asia. More than $70 \%$ of world's green gram production comes from India and accounts for about 10 to $12 \%$ of total pulse production in the country (Ministry of Agriculture, Government of India, 2014). It is also commonly known as mungbean. It is quite versatile crop grown for seeds, green manure and forage and it is also 
considered as "Golden Bean" because of its nutritive values and suitability for increasing the soil, by the way of addition of nitrogen to the soil.

Green revolution made our nation selfsufficient in cereals but we are still deficit in pulse production. India still imports Green Gram from countries like Myanmar, Australia and Africa to satisfy the pulse requirement. This impose great burden on our economy. Poor crop establishment is a major constraint for mungbean production (Naseem et al., 1997) (Rahmianna et al., 2000). Usually seeds with low vigour produce weak and unproductive plants (Olisa et al., 2010) and high yields can be associated with early vigor (Kumar et al., 2002). However rapid germination of seedlings could emerge and produce deep roots before the upper layers of the soil are dried and crusted, which may result in better crop establishment and higher crop yield (Ashraf et al., 2005). The successful establishment of crop mainly depends upon good quality seed. To provide higher quality seeds, scientists have developed new technologies called "Seed Enhancement Techniques". The main objective of this technique is to optimize the application of seed treatment products by improving the technical quality of seeds. The two important enhancement technologies are seed priming and seed hardening that have been employed successfully for many crops.

It is reported that seed hardening is one of the most important developments to help rapid and uniform germination and emergence of seeds and to increase seed tolerance to adverse environmental conditions (Heydecker et al., 1973, 1975; Harris et al., 1999). Seed hardening has presented promising, and even surprising results, for many seeds including the cereal seeds. The root system of mung bean mainly located in the upper $20-25 \mathrm{~cm}$ depth which, under dry conditions, transformed into short tuberized roots, unable to absorb proper moisture and nutrition for growing plants. Water stress at any stage of growth may causes changes in plant morphology, physiology and consequently affects crop growth. To overcome this stress condition seed hardening is done. Physiological seed treatments that enhance the performance of seed are based primarily on seed hydration and dehydration (May et al., 1962). Seed priming/hardening is a common practice followed to enhance seed performance with respect to rate and uniformity of germination (De Lespinay et al., 2010). In addition to better establishment, hardened crops grew more vigorously, flowered earlier and yielded higher (Farooq et al., 2008).

\section{Materials and Methods}

The present evaluation entitled "Effect of hardening on seedling characters, germination and nodulation in greengram (Vigna radiata L.) var. Samat." was conducted during Kharif 2016, in Post Graduate Laboratory of Seed Science and Field Experimentation Centre of the Department of Genetics And Plant Breeding, Sam Higginbottom, University of Agriculture, Technology and Sciences, Allahabad (U.P.). The treatments used at different concentrations for hardeaning were T0-Unhardened seeds (Control), T1-Distilled water, $\mathrm{T} 2-\mathrm{KNO}_{3}(20 \%)$, T3-NaCl (1\%), T4$\mathrm{CaCl}_{2}(1 \%)$, T5-Tulsi leaves extract $(5 \%)$ and T6-Neem leaves extracts (5\%).

For the preparation of solution one gram of each chemical was taken in a beaker. These chemicals were added separately in $1000 \mathrm{ml}$. of distilled water with constant stirring. The volume of solution will finally constitute to one litter, then it became 1000 ppm stock solution of each chemical. The flasks containing chemicals was covered with muslin cloth to avoid any contamination. For 
the preparation of $\mathrm{KNO}_{3}$ solution $\left(\mathrm{KNO}_{3}\right.$ $20 \%) 200 \mathrm{gm}$ of potassium nitrte was taken and mixed with $1000 \mathrm{~L}$ of distilled water. For the preparation of Sodium chloride $(\mathrm{NaCl}-$ $1 \%$ ) solution 10 (gm) $\mathrm{NaCl}$ was taken in a measuring flask and made up to $1000 \mathrm{ml}$. distilled water, while for $(1 \%)$ Calcium chloride $\left(\mathrm{CaCl}_{2}\right.$ ) solution $10(\mathrm{gm}) \mathrm{CaCl}_{2}$ salt was taken in a measuring flask and made up to $1000 \mathrm{ml}$ with distilled water and for Tulsi leaves extract solution $1 \mathrm{~kg}$ of tulsi leaves was taken and then grinded after this the matter is mixed with water and then water was strained out in a measuring flask, $50 \mathrm{ml}$ of tulsi leaves extract solution was taken and made up to $1000 \mathrm{ml}$ with distilled. By using the same procedure neem leaf extract solution was prepared, $50 \mathrm{ml}$ solution of Neem leaf extract was taken in a measuring flask and made up to $1000 \mathrm{ml}$ distilled water.

After preparation of solution of Potassium nitrate (KNO3), Sodium chloride $(\mathrm{NaCl})$, Calcium chloride $\left(\mathrm{CaCl}_{2}\right)$, Tulsi leaf extract, and Neem Leaf Extract, Greengram seeds were soaked in required solution for 12 hour at $25^{\circ} \mathrm{C}$ temperature. After $12 \mathrm{hrs}$ of soaking the solution was drained out from the beaker and pre-soaked seeds air dried or shade dried to original weight and then placed for germination in laboratory under controlled condition incompletely randomized design in between the paper (CRD) and in the field under RBD(randomized block design) where we observed nodulations.

The observations of the characters viz Germination percentage (ISTA 2004), Root length $(\mathrm{cm})$, shoot length $(\mathrm{cm})$, Seedling length $(\mathrm{cm})$, Seedling fresh weight $(\mathrm{gm})$, seedling dry weight (gm), Vigour index I, Vigour index II (Baki and Anderson,1973) were recorded. The experimental data recorded were subjected to analysis of variance, range, mean, and coefficient of variation (Fischer, 1936).

\section{Result and Discussion}

According to the results, all studied traits were affected by the treatments and there was completely significant difference between control (unhardened seeds) and Hardened seeds (Tables 1, $2 \& 3$ ). Seed hardening means alternate drying and wetting of seeds (Pen aloza and Eira, 1993). More than one pre-sowing treatment causing an increase in seed weight and it was reported by Vijaya (1996) in cowpea and blackgram, Maheshwari (1996)

The mean performance of germination percentage ranged from $76.16 \%$ to $86.01 \%$ with mean value of $81.50 \%$. Significantly highest percentage of germination $(86.01 \%)$ was reported in the seeds hardened with $\mathrm{T}_{2} \mathrm{KNO}_{3} 20 \%$ and it was followed by $\mathrm{T}_{6}$ Neem leaf extract solution i.e., $85.20 \%$ and seeds hardened with calcium chloride $\left(\mathrm{CaCl}_{2}\right) \quad 1 \%$ shows $81.04 \%$ germination. Minimum germination percentage was recorded by $\mathrm{T}_{0}$ seeds i.e., $76.16 \%$ with unhardened control.

It has been reported that hardened seeds showed better germination pattern and higher vigour level than non- hardened seeds (Ruan et al., 2002). The stimulatory effect on germination and the growth of seedlings of hardened seed could be due to the fertilizing effect resulting from the nutrient release from damaged or decayed tissue of storage organ by hydrolysis (Orr et al., 2005).

The mean performance of seedling root length ranged from $12.21 \mathrm{~cm}$ to $16.06 \mathrm{~cm}$ with mean value of $13.93 \mathrm{~cm}$. Maximum root length $(16.06 \mathrm{~cm})$ was recorded by $\mathrm{T}_{2}$ hardened with $\mathrm{KNO}_{3} 20 \%$ and it was followed by $\mathrm{T}_{6}(15.18$ $\mathrm{cm})$ hardened with Neem leaf extract 5\% followed by $\mathrm{CaCl}_{2}$ i.e., $14.02 \mathrm{~cm}$ and Minimum root length was recorded by $\mathrm{T}_{0}$ i.e., $12.21 \mathrm{~cm}$ that is unhardened seeds. 
The mean performance of seedling shoot length ranged from $19.7 \mathrm{~cm}$ to $24.01 \mathrm{~cm}$ with mean value of $21.70 \mathrm{~cm}$. Maximum shoot length $(24.01 \mathrm{~cm})$ was recorded by $\mathrm{T}_{2}$ hardened with $\mathrm{KNO}_{3} 20 \%$ and it was followed by $\mathrm{T}_{6}(23.96 \mathrm{~cm})$ hardened with Neem leaf extract $5 \%$. The shortest shoot length was found in $\mathrm{T}_{0}$ unhardened control $(19.7 \mathrm{~cm})$.

The mean performance of seedling length ranged from $32.56 \mathrm{~cm}$ to $39.91 \mathrm{cmwith}$ mean value of $35.59 \mathrm{~cm}$. Maximum seedling length $39.91 \mathrm{~cm}$ was recorded by $\mathrm{T}_{2}$ hardened with $\mathrm{KNO}_{3} 20 \%$ and it was followed by $\mathrm{T}_{6}$ $39.24 \mathrm{cmhardened}$ with Neem leaf extract $5 \%$ and shortest seedling length was recorded in $\mathrm{T}_{0}$ unhardened control i.e., $32.56 \mathrm{~cm}$.
The higher seedling length in $\mathrm{KNO}_{3}$ is due to cumulative positive effect of $\mathrm{H}_{2} \mathrm{O}$ and $\mathrm{K}$ on root and shoot growth. There are reports that hydration of seeds that equals, but does not exceed, the lag phase of hardening permits early DNA replication, increased RNA and protein synthesis, greater ATP availability, faster embryo growth, repair of deteriorated seed parts (Karssen et al., 1989; Saha et al., 1990), and reduced leakage of metabolites than checks (Giri and Schillinger, 2003).

All these causes increased in seed root and shoot length which ultimately increased the total seedling length. The mean performance of seedling fresh weight ranged from $2.18 \mathrm{gm}$ to $3.38 \mathrm{gmw}$ ith mean value of $2.61 \mathrm{gm}$.

Table.1 Analysis of variance for seedling characters in greengram

\begin{tabular}{|c|c|c|c|}
\hline \multirow{2}{*}{ S. No. } & \multirow{2}{*}{ Characters } & \multicolumn{2}{|c|}{ Mean sum of squares } \\
\cline { 3 - 4 } & & Treatments $(\mathbf{d f}=\mathbf{6})$ & Error $(\mathbf{d f}=\mathbf{2 1})$ \\
\hline 1. & Germination Percentage & $40.13^{*}$ & 0.40 \\
\hline 2. & Root Length & $6.74^{* *}$ & 0.68 \\
\hline 3. & Shoot Length & $12.36^{*}$ & 1.47 \\
\hline 4. & Seedling Length & $39.49^{* *}$ & 3.52 \\
\hline 5. & Seedling Fresh Weight & $0.75^{* *}$ & 0.12 \\
\hline 6. & Seedling Dry Weight & $0.048^{*}$ & 0.007 \\
\hline $7 .$. & Seed Vigour Index I st $^{\text {nt }}$ & $540744.64^{* *}$ & 64512.0009 \\
\hline 8. & Seed Vigour Index I & 63.001 \\
\hline
\end{tabular}

* And ** significant at $5 \%$ and $1 \%$ level of significance, respectively

Table.2 Mean performance of Greengram for agronomic characters

\begin{tabular}{|c|c|c|}
\hline S. No. & Treatments & No. of nodulation (45 DAS) \\
\hline 1 & $\mathbf{T}_{\mathbf{0}}$ & 15.80 \\
\hline 2 & $\mathbf{T}_{\mathbf{1}}$ & 17.60 \\
\hline 3 & $\mathbf{T}_{\mathbf{2}}$ & 19.26 \\
\hline 4 & $\mathbf{T}_{\mathbf{3}}$ & 16.33 \\
\hline 5 & $\mathbf{T}_{\mathbf{4}}$ & 18.46 \\
\hline 6 & $\mathbf{T}_{\mathbf{5}}$ & 18.06 \\
\hline 7 & $\mathbf{T}_{\mathbf{6}}$ & 18.5 \\
\hline \multicolumn{2}{|c|}{ Grand Mean } \\
\hline C.D. (5\%) & $\mathbf{1 7 . 1 2}$ \\
\hline \multicolumn{2}{|c|}{ SE(m) } & 1.983 \\
\hline \multirow{2}{*}{ RANGE } & MIN & 0.643 \\
\cline { 2 - 4 } & MAX & $\mathbf{1 4 . 8 3}$ \\
\hline
\end{tabular}


Table.3 Mean performance of greengram for 8 seedling characters

\begin{tabular}{|c|c|c|c|c|c|c|c|c|c|}
\hline S.No. & $\begin{array}{l}\text { Treat } \\
\text { ments }\end{array}$ & $\begin{array}{l}\text { Germinati } \\
\text { on } \%\end{array}$ & $\begin{array}{c}\text { Root } \\
\text { Length } \\
\text { (cm) }\end{array}$ & $\begin{array}{c}\text { Shoot } \\
\text { Length } \\
\text { (cm) }\end{array}$ & $\begin{array}{c}\text { Seedling } \\
\text { Length } \\
\text { (cm) }\end{array}$ & $\begin{array}{c}\text { Fresh } \\
\text { Weight of } \\
\text { Seedling } \\
\text { (gm) }\end{array}$ & $\begin{array}{c}\text { Dry Weight } \\
\text { of Seedling } \\
\text { (gm) }\end{array}$ & $\begin{array}{c}\text { Seed } \\
\text { Vigour } \\
\text { Index I I }^{\text {st }}\end{array}$ & $\begin{array}{l}\text { Seed Vigour } \\
\text { Index II }^{\text {nd }}\end{array}$ \\
\hline 1 & $T_{0}$ & 76.16 & 12.21 & 19.7 & 32.56 & 2.18 & 0.37 & 2431.87 & 28.15 \\
\hline 2 & $T_{1}$ & 79.61 & 13.01 & 20.3 & 33.2 & 2.28 & 0.46 & 2656.25 & 36.73 \\
\hline 3 & $\mathbf{T}_{2}$ & 86.01 & 16.06 & 24.01 & 39.91 & 3.38 & 0.68 & 3451.73 & 58.96 \\
\hline 4 & $T_{3}$ & 80.28 & 13.67 & 20.33 & 34.9 & 2.37 & 0.59 & 2732.31 & 47.81 \\
\hline 5 & $\mathbf{T}_{4}$ & 81.04 & 14.02 & 21.31 & 33.81 & 2.48 & 0.58 & 2869.37 & 47.4 \\
\hline 6 & $\mathbf{T}_{5}$ & 82.19 & 14.48 & 22.02 & 35.5 & 2.54 & 0.59 & 3006.24 & 48.71 \\
\hline 7 & $T_{6}$ & 85.20 & 15.18 & 23.96 & 39.24 & 3.02 & 0.65 & 3339.09 & 55.82 \\
\hline \multicolumn{2}{|c|}{ Grand Mean } & 81.50 & 13.93 & 21.70 & 35.59 & 2.61 & 0.56 & 2897.59 & 46.28 \\
\hline \multirow{2}{*}{\multicolumn{2}{|c|}{$\begin{array}{c}\text { C.D.(5\%) } \\
\text { SE(m) }\end{array}$}} & 4.54 & 1.21 & 1.78 & 0.90 & 0.52 & 0.12 & 373.49 & 11.67 \\
\hline & & 1.54 & 0.41 & 0.60 & 0.30 & 0.17 & 0.04 & 126.99 & 3.96 \\
\hline \multirow[b]{2}{*}{ RANGE } & MIN & 76.6 & 12.21 & 19.7 & 32.56 & 2.18 & 0.37 & 2431.87 & 28.15 \\
\hline & MAX & 86.01 & 16.06 & 24.01 & 39.91 & 3.38 & 0.68 & $\mathbf{3 4 5 1 . 7 3}$ & $\mathbf{5 8 . 9 6}$ \\
\hline
\end{tabular}

Maximum seedling fresh weight (3.38gm) was recorded by $\mathrm{T}_{2}$ hardened with $\mathrm{KNO}_{3} 20 \%$ and it was followed by $\mathrm{T}_{6}(3.02 \mathrm{gm})$ hardened with Neem leaf extract $5 \%$ and Lowest value of seedling fresh weight was found in $\mathrm{T}_{0}$ unhardened control $(2.18 \mathrm{gm})$. The cumulative positive effect of the hardening on seed root length and shoot length causes to increase in fresh weight of the seedling.

The mean performance of seedling dry weight ranged from $0.37 \mathrm{gm}$ to $0.68 \mathrm{gmw}$ ith mean value of $0.56 \mathrm{gm}$. Maximum seedling dry weight $(0.68 \mathrm{gm})$ was recorded by $\mathrm{T}_{2}$ hardened with $\mathrm{KNO}_{3} 20 \%$ and it was followed by $\mathrm{T}_{6}$ $(0.65 \mathrm{gm})$ hardened with Neem leaf extract $5 \%$ and Lowest value of seedling dry weight was found in $\mathrm{T}_{0}$ unhardened control $(0.37 \mathrm{gm})$.

The mean performance of seedling vigour index $I^{\text {st }}$ ranged from 2431.87 to 3451.73 with mean value of 2897.59 .

Maximum seedling vigour index $\mathrm{I}^{\mathrm{st}}(3451.73)$ was recorded by $\mathrm{T}_{2}$ primed with $\mathrm{KNO}_{3}$ $20 \%$ and it was followed by $\mathrm{T}_{6}$ (3339.09) hardened with neem leaf extracts $5 \%$ and Minimum seedling vigour index $\mathrm{I}^{\text {st }}$ was recorded by $\mathrm{T}_{0}$ unprimed (2431.87) in control (Unhardened seeds).
The mean performance of seedling vigour index II $^{\text {nd }}$ ranged from 28.15 to 58.96 with mean value of 46.28. Maximum seedling vigour index $\mathrm{II}^{\text {nd }}$ (58.96) was recorded by $\mathrm{T}_{2}$ primed withKNO $\mathrm{KN}_{3} 20 \%$ and it was followed by $\mathrm{T}_{6}$ (55.82) hardened with Neem leaf extract 5\% Minimum seedling vigour index II $^{\text {nd }}$ was recorded by unhardened $\mathrm{T}_{0}(28.15)$ in control.

\section{Field observation}

The mean performance of number of nodulations per plant ranged from 15.80 to 19.26 with mean value of 17.12. Maximum number of nodulations per plant (19.26) was recorded by $\mathrm{T}_{2}$ hardened with $\mathrm{KNO}_{3} 20 \%$ and it was followed by $\mathrm{T}_{6}(18.50)$ hardened with Neem leaf extract 5\% and Minimum number of nodulations per plant was recorded by $\mathrm{T}_{0}$ (15.80) unhardened seeds.

Hardening with $\mathrm{KNO}_{3} 20 \%$ solution recorded significantly higher values for growth and yield attributing characters, viz., nodulation at 45 days after sowing (DAS), respectively, number of pods per plant (19.26), in compared with other treatments. Neem leaf extract 5\% also shows at par results when compared to other treatments. Hardening with 
$\mathrm{KNO}_{3} \quad 20 \%$ solution recorded significantly higher values for seedling characters, viz., seed germination percentage $(86.01 \%)$, shoot length $(24.01 \mathrm{~cm})$, root length $(13.01 \mathrm{~cm})$, seedling length $(33.31 \mathrm{~cm})$, seed vigour index $\mathrm{I}^{\text {st }}$ (3451.73), seed vigour index II $^{\text {nd }}(58.96)$, seedling fresh weight $(3.38 \mathrm{gm})$ and seedling dry weight $(0 . .68 \mathrm{gm})$ in compared with other treatments. Neem leaf extract $5 \%$ also shows at par results when compared to other treatments.

Soaking of seed with Neem solution is also advantageous to obtain healthy seedlings. The root system of mung bean mainly located in the upper 20-25 cm depth (Kjellstrom, 1991) which, under dry conditions, transformed into short tuberized roots, unable to extract proper moisture and nutrition for growing plants. Water stress at any stage of growth may causes changes in plant morphology, physiology and consequently affects crop growth (Hashem et al., 1998). To overcome this stress condition seed hardening is done.

\section{Acknowledgement}

Authors are thankful to Dr. A. K. Chaurasia, Associate Professor Department of Genetics and Plant Breeding, SHUATS, Allahabad, Uttar Pradesh (U.P), India for providing necessary facilities, encouragement and support.

\section{References}

Ashraf, M., Foolad MR 2005. Pre-sowing seed treatment-A Shotgun approach to Improve Germination, Plant growth, and crop Yield under Saline and Nonsaline Conditions. Advan. Agron. 88: 223-276

Baki and Anderson JD 1973. Vigour determination in soyabean seeds by multiple criteria. Crop Science 13:630633
De Lespinay, A., H. Lequeux, B, Lambillottee and S. Lutts, 2010. Protein synthesis is differentially required for germination in Poapratensis and Trifolium repens in the absence or in the presence of cadmium. Plant Growth Regul., 61: 205-214

Farooq, M., Basra SMA, Cheema MA, Afzal I 2008. Integration of presowing soaking, chilling and heating treatments for vigor enhancement in rice (Oryza sativa L.). Seed Sci Technol. 34: 499506

Fisher R.A., 1936. "The use of multiple measurements in taxonomic problems." Annals of Eugenics 7: 179188

Giri, S.G., Schillinger WF. 2003. Seed priming winter wheat for germination, emergence, and yield. Crop Sci. 43: 2135-2141

Hariprasanna, K., and Bhatt, J. 2002. Pulse production looking at constraints and prospects. Agriculture today, Aug, 4953

Harris, D., Joshi A, Khan PA, Gothakar P, Sodhi PS. 1999. On-farm seed priming in semi-arid agriculture: Development and evaluation in corn, rice and chickpea in India using participatory methods. Exp. Agric. 35 15-29

Hashem, A.M., Maiumdar NA, Hameed A, Hossain MM 1998. Drought stress effects on seed yield, yield attributes, growth, cell membrane stability and gas exchange of synthesized (Brassic. Napus L.) J. Agron. Crop Sci. 180: 129136.

Heydecker, W., 1974. Germination of an idea: The priming of seeds. University of Notingham School of Agriculture Report. PP. 50-67

ISTA, 2004. International rules for seed testing. Seed Sci., \& Technol., Supplement Rules: 27-57. 
Kjellstrom, C., 1991. Growth and distribution of the root system in Brassica napus. In: D. I. McGregor (Ed.). Proceedings of the eight International rapeseed Congress, Saskatoon, Canada. pp.722726

Kumar, R., Tyagi CS, Ram C 2002. Association of laboratory seed parameters with field performance in mung bean. Seeds and Farms. 15: 3336.

Maheshwari, R., 1996. Seed production technology in soyabean under rice fallow and methods to control seed Deterioration in soyabean cv. $\mathrm{CO} 1$ (Glycine max L. Merril). M.Sc. (Ag.) Thesis, Tamil Nadu Agriculture University, Coimbatore

May, L.H., Milthrope, E.J and Miklthrope, F.L. 1962. Pre-sowing hardening of plants to drought. Field Crop Abstr.,15: 93-98.

Naseem, S.B., Khan AH, Islam M, Mollah U, Ali MA 1997. Effect of seeding methods and varying surface soil moisture on the stand establishment of mung bean (Vigna radiata L.). Bang. J. Sci. Indus. Res. 32: 295-301
Olissa, et al., 2010. Article in Research Journal of Seed Science 3(2):93-101 . February 2010. low vigor (Powell et al., 1984.

Orr. S.P., Jennifer, A., Rudgers, A., and. Clay, K. 2005. Invasive plants can inhibit native tree seedlings: testing potential allelopathic mechanisms. Plant Ecology, 181: 153 - 165

Pen Aloza A.P.S., Eira M.T.S. 1993. Hydration- dehydration treatments on tomato seeds (Lycopersicon esculentum Mill). Sees Science and Technology, 21, 309-316.

Rahmianna, A.A., Adisarwanto T, Kirchhof G 2000. Crop establishment of legumes in rainfed lowland rice-based cropping systems. Soil Till. Res. 56 (1/2): 67-82.

Ruan, S., Q. Xue and R. Tylkowska, 2002. Effects of seed priming on germination and health of rice (Oryza sativa L.) seeds. Seed Sci. Technol., 30: 451-458.

Saha, R., A.K. Mandal and R.N. Basu, 1990. Physiology of seed invigoration treatments in soybean (Glycine max L.). Seed. Seed Technology and its Biological Basis, Sheffield Academic Press, Sheffield, UK, 1999, pp: 287325.

\section{How to cite this article:}

Shivanisingh, A.K. Chaurasia, Bineeta M. Bara and Vijay Dugeskar. 2017. Effects of Hardening Methods on Seedling Characters, Germination and Nodulation in Greengram (Vigna radiata L.). Int.J.Curr.Microbiol.App.Sci. 6(9): 2297-2303.

doi: https://doi.org/10.20546/ijcmas.2017.609.281 